\title{
INSIGHT ANALYSIS ON DYKE PROTECTION AGAINST LAND SUBSIDENCE AND THE SEA LEVEL RISE AROUND NORTHERN COAST OF JAVA (PANTURA) INDONESIA
}

\author{
H. Andreas ${ }^{a}$ (D) , H. Z. Abidina (iD) , D. A. Sarsito a (iD) , D. Pradipra ${ }^{a}$ \\ ${ }^{a}$ Geodesy Research Group, Bandung Institute of Technology, Indonesia
}

Article Info:

Received: 06 August 2017

in revised form: 10 Dec 2017

Accepted: 30 January 2018

Available Online: 30 April 2018

Keywords:

Geodesy, Geography, Geomatics, Civil,

Urban and Regional Planning

Corresponding Author:

Heri Andreas

Geodesy Research Group, Bandung

Institute of Technology, Indonesia

Email: heriandreas49@gmail.com

\begin{abstract}
Land subsidence and the sea level rise is newly well-known phenomenon around northern coast of Java Indonesia (PANTURA). The occurrence of land subsidence at least recognizes at the first of the city or urban area development, while the sea level rise was recognized from several last decades corresponds to the global warming. Following the both phenomena, tidal inundation (in Javanese they call it "Rob") is now becoming another newly well-known phenomenon along PANTURA. In the recent years the tidal inundation comes not only at a high tide but even at the regular tide in some area. Sea level rise and the land subsidence are considered as the causes deriving the occurrence of tidal inundation. Dykes have been built against tidal inundation around PANTURA (e.g. in Jakarta, Blanakan, Pekalongan, Semarang, and Demak). Nevertheless, since the land subsidence and the sea level rise are believed to be continuing through times, insight analysis on these dyke's "protector" is necessary. How long the dyke would effectively protect the land area would be highlight in this paper.
\end{abstract}

How to cite (APA 6th style): Andreas, H. et al. (2018). Insight analysis on dyke protection against land subsidence and the sea level rise around Northern Coast of Java (PANTURA) Indonesia. Geoplanning: Journal of Geomatics and Planning, 5(1), 101-114. doi: 10.14710/geoplanning. 5(1), 101-114

\section{INTRODUCTION}

Northern coast of Java Indonesia is famous with the local name called PANTURA. It started from Merak in northern part of west of Java province crossed to about 1000-kilometer length to Banyuwangi in East Java Province (Figure 1). PANTURA existed along with the Java Sea. Many big cities develop along PANTURA such as Jakarta, Cirebon, Pekalongan, Semarang, and Surabaya. Despite of many features that can be found in PANTURA, land subsidence, sea level rise, and tidal inundation are there as very interesting features. Land subsidence and the sea level rise is newly well-known phenomenon around PANTURA. The occurrence of land subsidence at least recognizes at the first of the city or urban area development, while the sea level rise was recognized from several last decades corresponds to the global warming. As the consequences of land subsidence and the sea level rise phenomena, tidal inundation (in Javanese they call it "Rob") is becoming another newly well-known phenomenon along PANTURA. In the recent years the tidal inundation comes not only at a high tide but even at the regular tide in some area.

Land subsidence by definition is a lowering the ground level from the reference height system such as geoids or the sea level. Excessive of Groundwater abstraction in combination with natural compaction of sediments and probably tectonic deformation, land setting/reclamation, loading from construction of new buildings, oil and gas extraction, underground mining, drainage of peat lands, etc. are considered as possible causes of the land subsidence. Meanwhile, the increasing temperature of the earth has been brought ice to melt in the north and south Antarctica and made volume of water larger. As the consequences the sea level rise exists. The tidal inundation simply explains as the flood coming from the sea because the land is lower than the sea level. The land subsidence is making the low land area along the coast become lowering through times than the sea level. Tidal inundation is become a disaster for several 
places around the coastal area like PANTURA. Many of urban and other areas like farming area, fishpond, etc. have been suffered tidal inundation and becoming worse in times. First it was only few centimetres of inundation and come only at a high tide, but now it can be more than a half of meter and coming at regular tide, and even has comes permanently in certain places.

Dykes have been built against tidal inundation disaster around PANTURA (e.g. in Jakarta, Blanakan, Pekalongan, Semarang, and Demak). Nevertheless, as we will see on the paper, since the land subsidence and the sea level rise are believed to be continuing through times, insight analysis on these dyke's "protector" is necessary. How long the dyke would effectively protect the land area would be highlight in this paper along with others analysis.

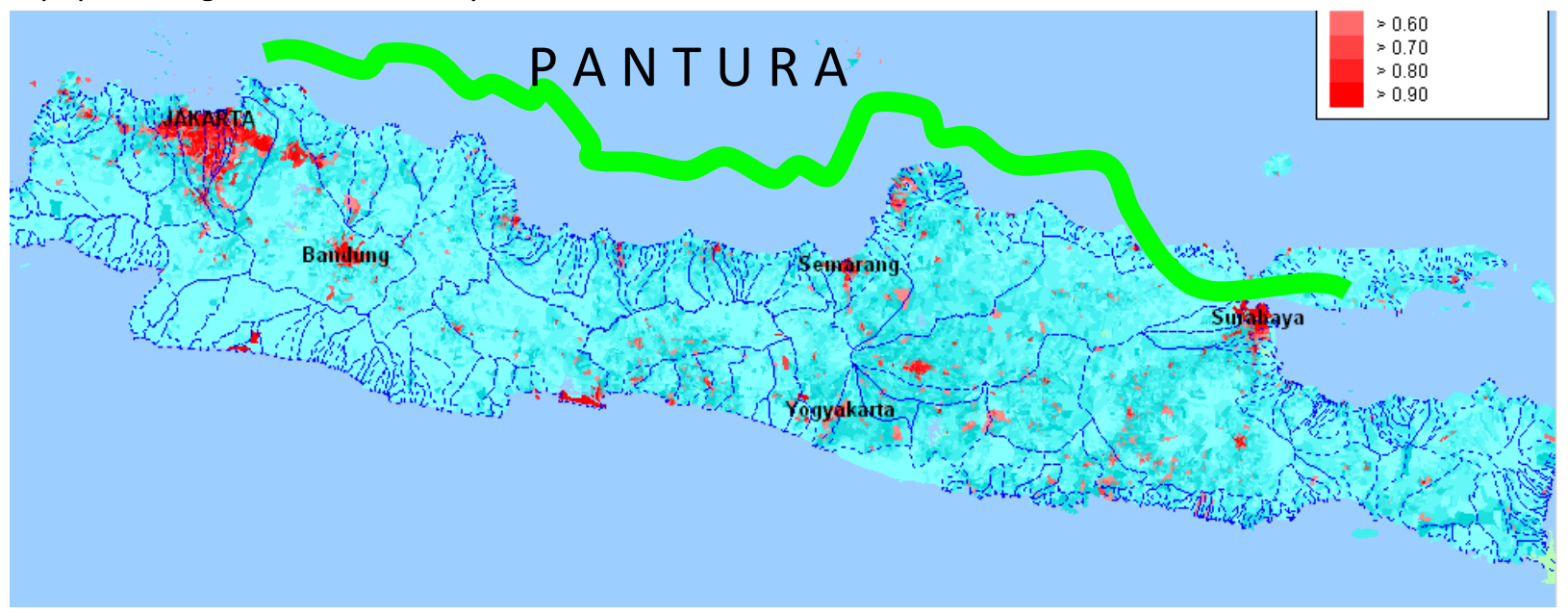

Figure 1. The Map of PANTURA. Red color represents urban area (Source: Deltares)

\section{DATA AND METHODS}

\subsection{Land Subsidence}

For building the dyke along PANTURA we absolutely need to understand beforehand about the land subsidence characteristic. It is most probably the dyke will be sinking due to subsidence. In this case, knowing the rate of the subsidence and the longevity of the subsidence are important parameters for dyke design, etc. As for PANTURA, the land subsidence is clearly taking places in Jakarta, Pondok Bali Blanakan, Cirebon, Pekalongan, Semarang, Demak and Surabaya (Figure 2). The evidence for subsidence was based on repeated levelling measurements, GPS surveys, InSAR measurements, extensometer, etc.

Levelling is a very conventional of geodetic technique measuring height from reference point connected to the Mean Sea Level (MSL). Repeated measurement of levelling in the same point in some are may revealed land subsidence information. GPS (Global Positioning System) is a passive, all-weather satellitebased navigation and positioning system, which is designed to provide precise three dimensional positions and velocity, as well as time information on a continuous worldwide basis (Hofmann-Wellenhof et al., 2008; Abidin et al., 2008). InSAR is satellite base imagery that can provide better understanding in spatial variation of land subsidence, which become the weakness of GPS method. Some researchers have been conducted to perform land subsidence monitoring by InSAR, such as (Chaussard et al., 2013; Koudogbo et al., 2012; Kuehn et al., 2009), etc.

The occurrence of land subsidence in Jakarta was recognized at least in the early the development of the city. According to some publications (e.g. H. Abidin et al., 2010; H Z Abidin, 2005; H Z Abidin et al., 2004; Hasanuddin Z Abidin et al., 2008; Hasanuddin Z Abidin et al., 2011; Chaussard et al., 2013; Koudogbo et al., 2012; D Murdohardono \& Sudarsono, 1998; Dodid Murdohardono \& Tirtomihardjo, 1993; Ng et al., 2012; Rajiyowiryono, 1999) the yearly value of Jakarta's subsidence generally ranging from 1 to 10 centimeter per-year and may reach 20-26 centimeter in certain place, especially in northern part of Jakarta for the recent years. Magnitude of subsidence of 4 meter and even more has been recognizing around Pluit area north of Jakarta. Ground water abstraction is one very dominant factor causing land subsidence in Jakarta. 
Pondok Bali Blanakan area is not a city but mostly farming and fishpond area while Pekalongan is a development of urban area. It is quite surprising that the land subsidence is happening in these areas with significant rate per year (1-10 centimeters). Tidal inundation is regularly flooded the areas. As being investigated, preliminary conclusion said that land subsidence in Pondok Bali Blanakan area is due to exploitation of oil and gas. In the area there are more than fifteen oil and gas platform facilities which are actively exploiting oil and gas in the area. Meanwhile Pekalongan is a center of Batik industry. The need of huge amount of water for washing Batik has predicted influence the land subsidence in the area. Preliminary result concludes that many Batik industry is taking groundwater in deep aquifer and as the consequences 1-10 centimeters of land subsidence per year existed in the area.

Land subsidence is not a new phenomenon for Semarang. Some report said the subsidence in Semarang probably is occurring for more than 100 years. The impact of land subsidence in Semarang can be seen in several forms, such as the wider expansion of (coastal) flooding areas, cracking of buildings and infrastructure, and increased inland sea water intrusion. It also badly influences the quality and amenity of the living environment and life (e.g. health and sanitation condition) in the affected areas. In the case of Semarang, comprehensive information on the characteristics of land subsidence is applicable to several important planning and mitigation efforts, such as effective control of coastal flood and seawater intrusion, spatial-based groundwater extraction regulation, environmental conservation, design and construction of infrastructure, and spatial development planning. According to some publications (Chaussard et al., 2013; Kuehn et al., 2009; Lubis et al., 2011; Marfai \& King, 2007; D Murdohardono et al., 2009; Sutanta et al., 2005) the yearly value of Semarang's subsidence generally ranging from 1 to 17 centimeter per-year.

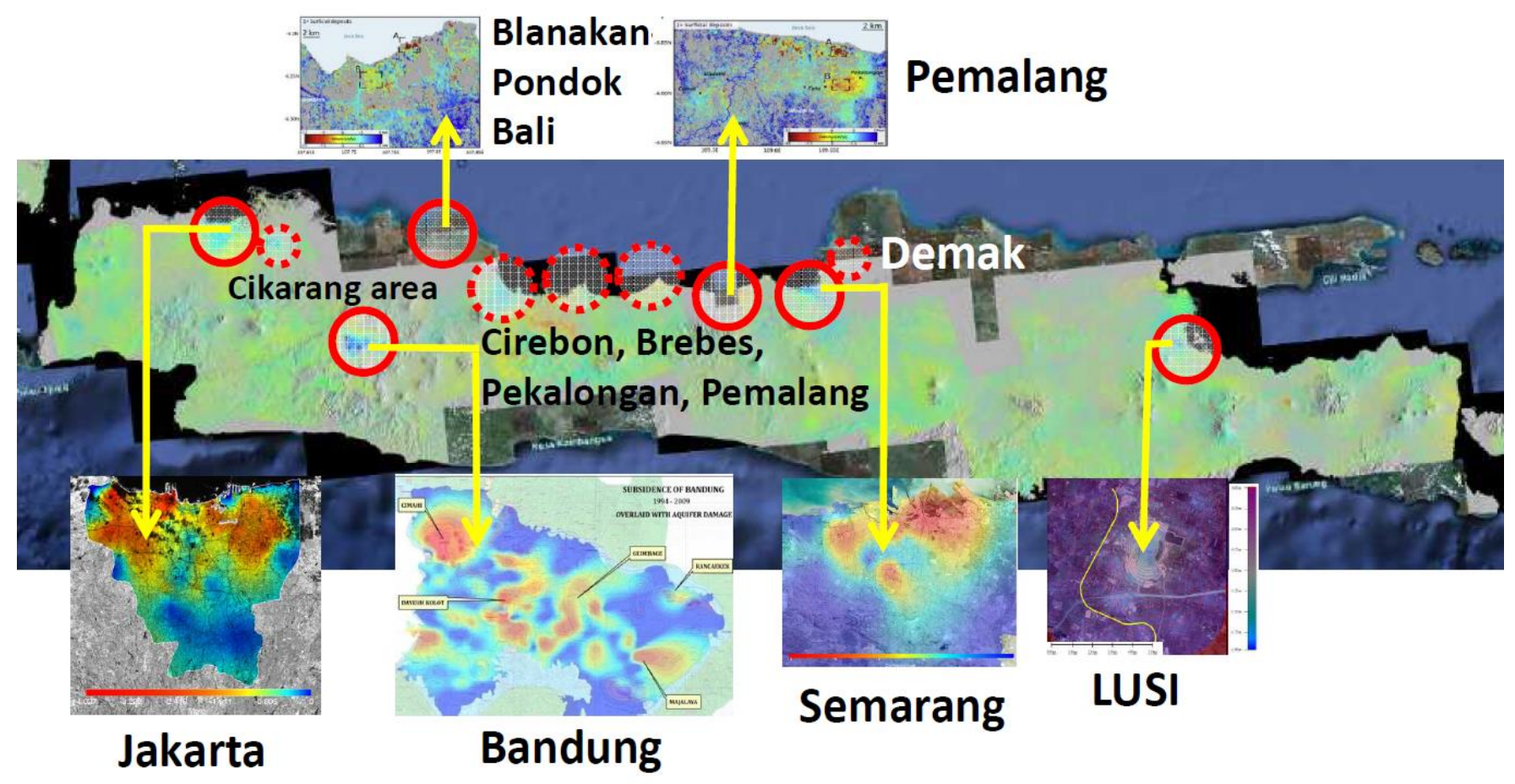

Figure 2. Map of subsidence along PANTURA (modified from Chaussard et al., 2013, Abidin et.al, 2008; $2010 ; 2011)$

Table 1 shows average rate of land subsidence in Jakarta, Pondok Bali Blanakan, Pekalongan, Semarang, Demak, Surabaya area, and other places around PANTURA. High rate of subsidence is taking places in Jakarta and Semarang. Hugh development on the city, especially in Jakarta has created such rate. If the rate is continuing, in combining with the sea level rise, they will derive tidal inundation in larger area. That is a very potential disaster to PANTURA. 
Table 1. Average rate of land subsidence in Jakarta, Pondok Bali Blanakan, Pekalongan, Semarang, Demak, Surabaya, and other places around PANTURA

\begin{tabular}{ccc} 
No & Area & Average rate of subsidence (meter/year) \\
\hline $\mathbf{1 .}$ & Jakarta & $0.010-0.150$ \\
\hline $\mathbf{2 .}$ & Bekasi Cikarang & $0.010-0.100$ \\
\hline $\mathbf{3 .}$ & Pondok Bali Blanakan & $0.010-0.100$ \\
\hline $\mathbf{4 .}$ & Cirebon & $0.005-0.020$ \\
\hline $\mathbf{5 .}$ & Pekalongan & $0.010-0.100$ \\
\hline $\mathbf{6 .}$ & Semarang \& Demak & $0.010-0.150$ \\
\hline 7. & Surabaya & $0.010-0.030$ \\
\hline
\end{tabular}

\subsection{Sea Level Rise}

The increasing temperature of the earth has been brought ice to melt in the north and south Antarctica and made volume of water larger (Figure 3). As the consequences the sea level rise exists. Figure 4 show graph of sea level rise that is happening in the ocean worldwide from recorded of tide gauges (1970-2005) and Satellite Altimetry data (1992-2010) reported by IPCC. Generally the sea level rise is ranging in order millimetre to few centimetres per year. Only few places in the world are experiencing in larger magnitude, but it is not more than a few decimetres per year. This sea level rise even in the small magnitude in theory can also influence the tidal inundation respectively. The sea in Indonesia especially around northern part of Java is experiencing sea level rise in order of few millimetres per year (Nurmaulia et al., 2010).

Satellite altimetry is satellite base geodetic technique that has good capability in sensing sea level rise from the satellite. By using electromagnetic pulse we can measure the range from sea surface (footprint) to the satellite with accuracy in order of few centimetres. The satellite is equipped with the GPS (Global Positioning System) that can provide height of either satellite or sea surface above ellipsoid reference system.

In the future the total magnitude of sea level rise may reach meters level. In this case, for low land coastal area it would be prone to inundation. Dyke is one solution to protect land from inundation. Another possibility is to higher the land through reclamation. As for the case of combination of land subsidence and the sea level rise, we won't wait another longer to establish the dyke since the inundation comes earlier. As explained previously what happens in PANTURA is combination of them.
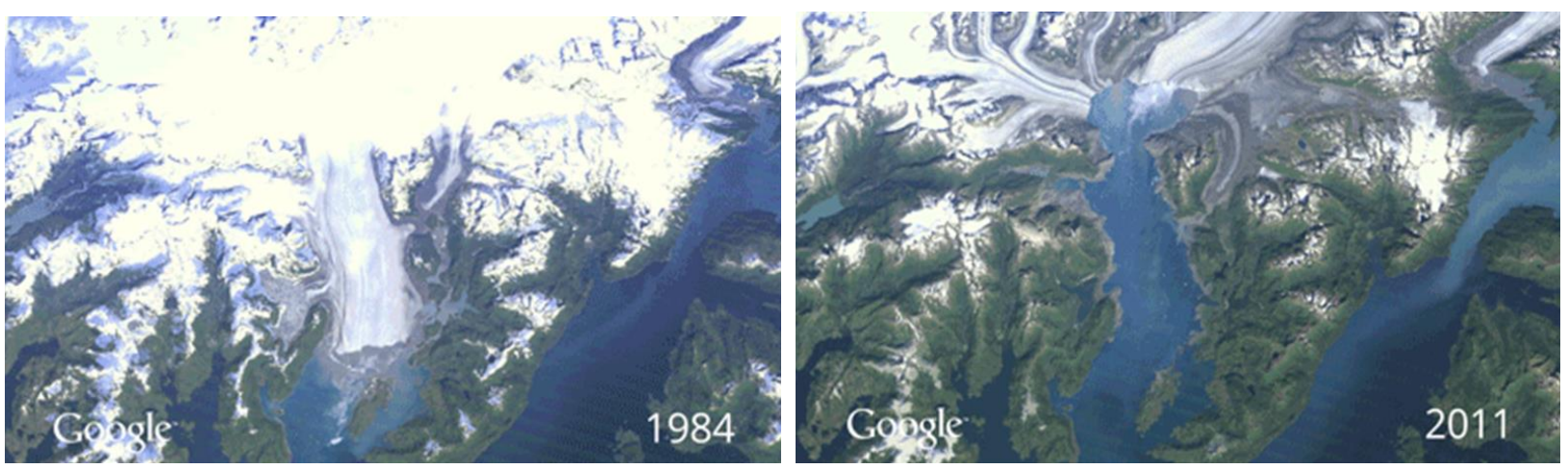

Figure 3. Courtesy of Google satellite image taken in 1984 and 2011 around Antarctica showing decreasing in ice volume 


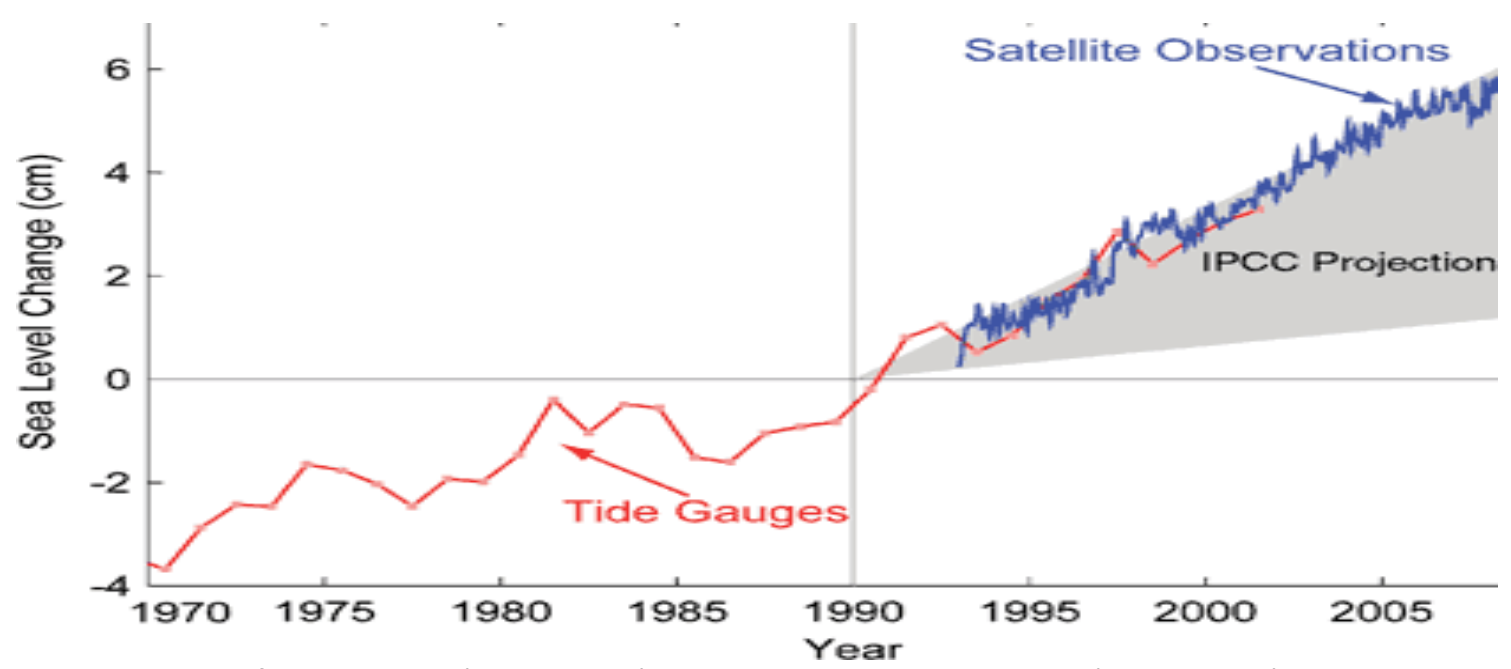

Figure 4. Recorded of tide gauges (1970-2005) and Satellite Altimetry data (1992-2010) indicating sea level rise (in centimeter scale) as the consequences of global clime change (Modified from IPCC graph)

\subsection{Tidal Inundation}

Time series of high-resolution satellite image from all available google data archives (year 2000- recent years) together with any others similar available sources have been used to see tidal inundation. Generally, the pixels resolution for most of the images were below 1 meter. This is good enough to clearly interpret the inundation, etc. if the images uncovered by the clouds. By this approach we may identify all of tidal inundation areas along PANTURA. We used the newest until the oldest satellite image available data one by one. From the images, we delineate the old predicted of coast line with new probable coastline (either sharp inward of abrasion, far inland of tidal inundation or toward the sea of sedimentation), and then we made polygon area to represent the area that at least being inundated, suffering abrasion or, expanded due to sedimentation (see example in Figure 5).

As the cased of tidal inundation that would be the focus in this research, to delineate the exact line we have limitation on the image colors and tones interpretation since in the dense housing area or images timing being taken in the low tide, and therefore tones or colors of inundation was unclear. In order to make sure the true existence of tidal inundation area, in several place we done in-situ measurements. During the past years we conducted expedition to visit coastal area of northern Java. Place that we visited included Tanggerang, Jakarta, Bekasi, Pondok Bali, Blanakan, Pekalongan, Kendal, Semarang, Demak, Gresik, and Surabaya.

From all high resolution satellite image data that we have been collected, processed, and analyzed, we can see the tidal inundation, sedimentation, and also abrasion are taking place at least in Tanggerang, Jakarta, Bekasi, Pondok Bali, Blanakan, Indramayu, Cirebon, Brebes, Tegal, Pemalang, Pekalongan, Batang, Kendal, Semarang, Demak, Gresik, Surabaya, and Sidoarjo. If we add the results from the site visit and internet surfing, we would find many others area being inundated especially the temporary one. Figure 5 shows several figures of tidal inundation in most locations along northern coast of Java as result of above works. Since mentioned places are suffering tidal inundation, planning and execution in development dyke should be exist in these areas. How severe the inundation will influence how well the dyke should be design and establish.

\subsection{Dyke Protection}

Dyke to protect land from tidal inundation, sea level rise and perhaps the subsidence has been establishing in many part of PANTURA (Figure 6 and Figure 7). In Jakarta we can find dyke along Kamal Muara, Pantai Indah Kapuk, Muara Angke, Muara Karang, Pantai Mutiara, Muara Baru, Ancol, Tanjung Priok, and Maruda. The heights can be 1 up to 2 meters. Meanwhile, In Pondok Bali Blanakan we can find almost 1.5-meter dyke established to protect some village in the area. Few temporary dykes can be found along coastal area of Pekalongan. In Semarang and Demak area we can find dyke along Pantai Marina, Tanjung Mas, Tambak Loro, Kaligawe, Sayung, and Worosari. Many small dykes may be also found in others 
place around PANTURA from Tanggerang, Cirebon, Tegal, and up to Surabaya area. Occasionally the dyke can be seen created using the sand bag.
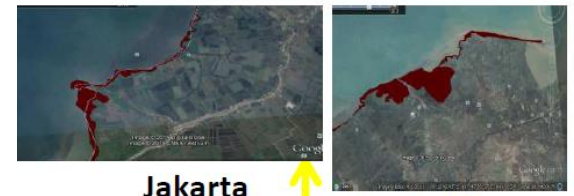

Jakarta

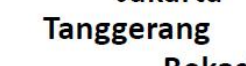

Bekasi
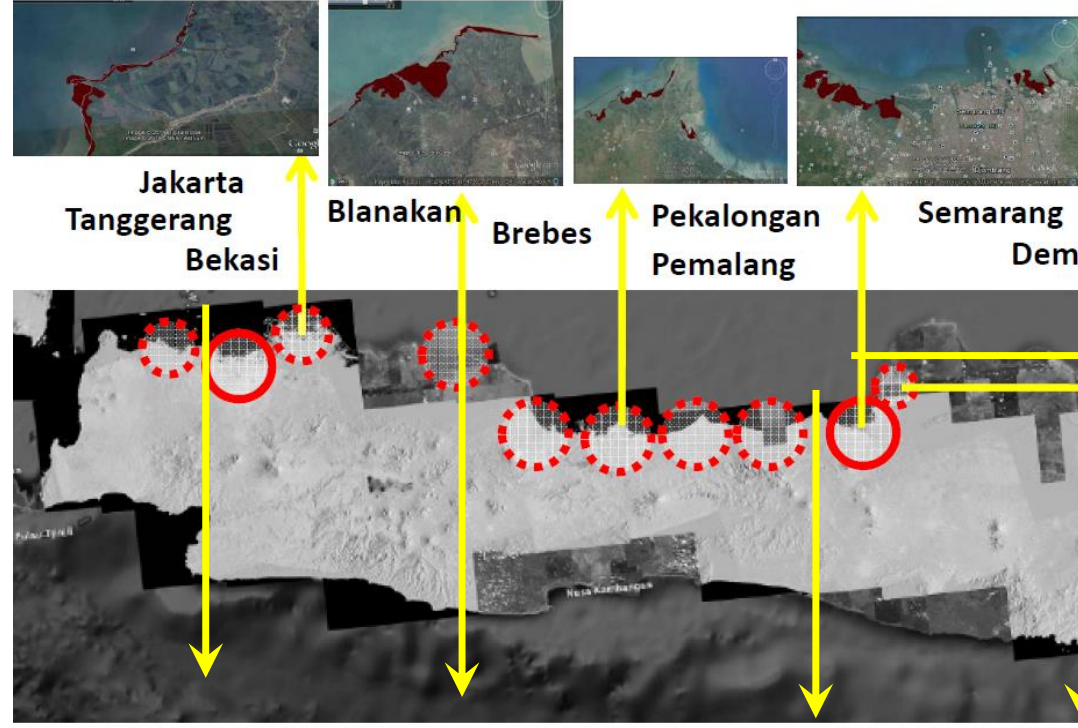

Demak

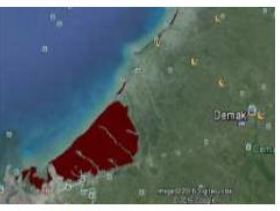

Gresik

Surabaya
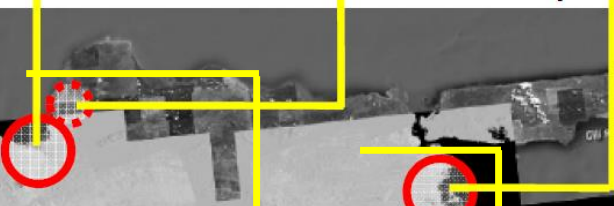
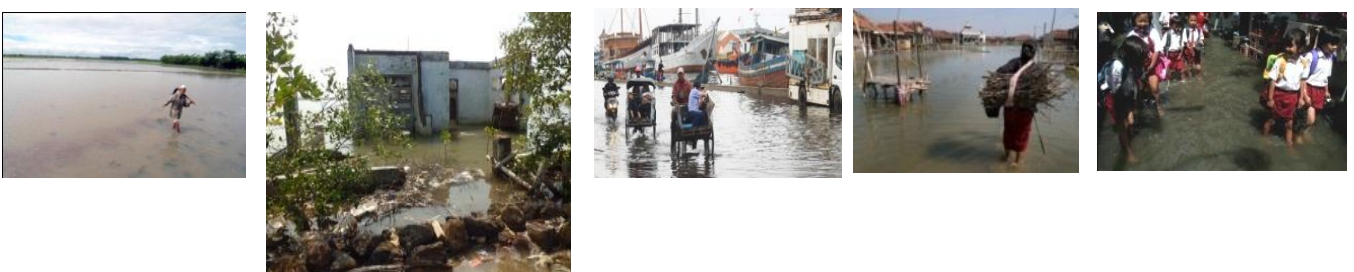

Figure 5. Tidal inundation, abrasion and sedimentation in most locations of PANTURA from all highresolution satellite images data and others supported data being collected and analized

For sometimes, these dykes are quite effective on protecting the land from tidal inundation, sea level rise, and perhaps the subsidence. There was a heavy tidal inundation in Jakarta back at 2007 where access to the airport was closed for one day leaving flight schedule in chaos. Now it seems like a history. In 2008 and 2009 almost half of north Semarang was experiencing severe tidal inundation. The water has reached even more than 2 kilometer inward the coastline. Now it seems dry. Nevertheless, on chapter result and discussion we will understand the real situation after done insight analysis to the dyke. The hint is that the dyke has longevity and it is not a final solution against the land subsidence and the sea level rise.
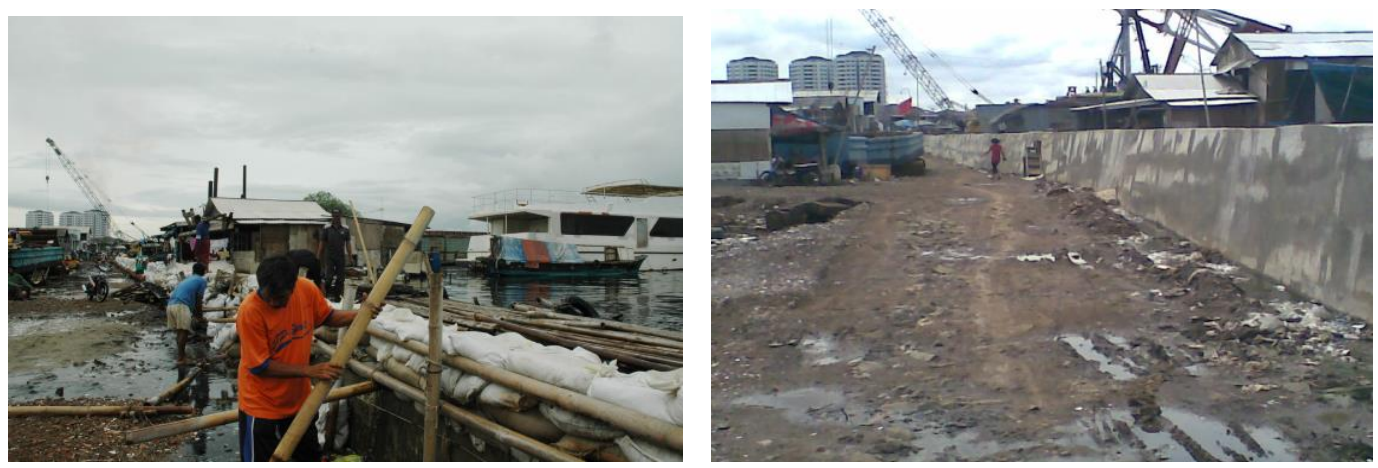

Figure 6. Picture on the left shows temporally dyke around Pluit area Jakarta using sand bag just after heavy tidal inundation in 2007, while on the right shows one-meter new dyke establish in 2008 


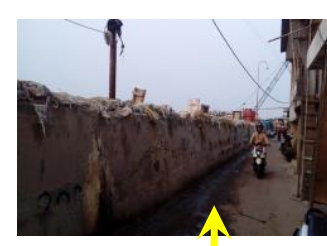

Jakarta

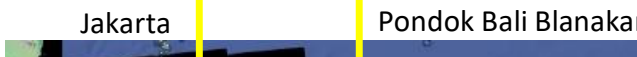

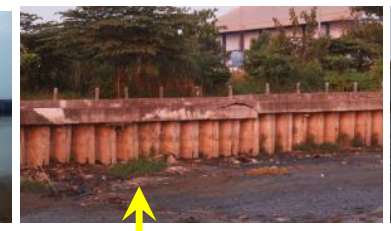

Semarang

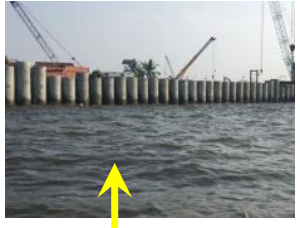

Demak

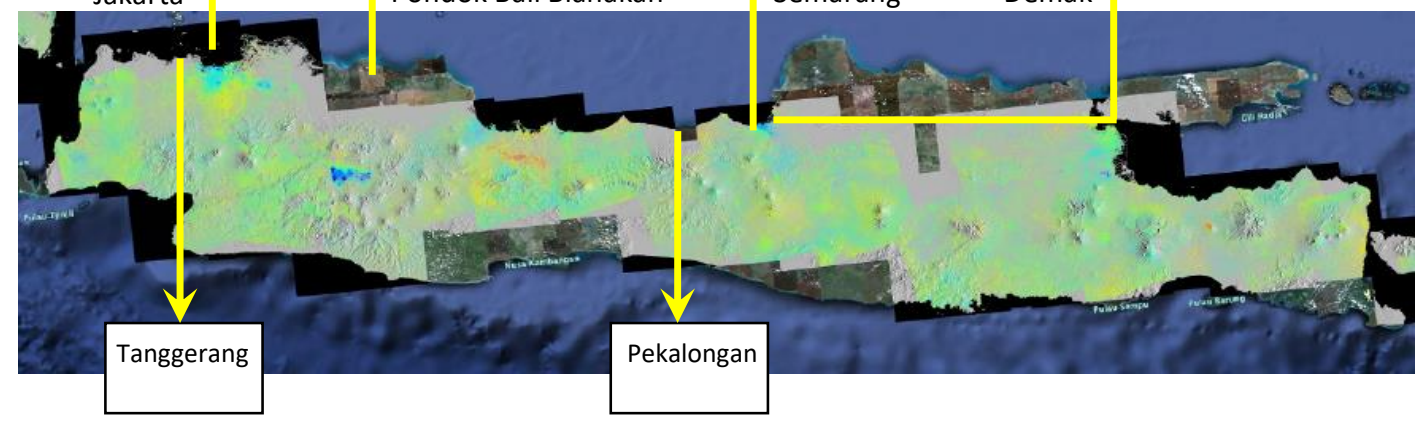

Figure 7. Dyke to protect land from tidal inundation, sea level rise and perhaps the subsidence has been establishing in many parts of PANTURA

Dyke program in bigger scale has been initiated in Jakarta. First initiated by the Jakarta Coastal Defense Study (JCDS), the scenario of "Giant Sea Wall" is establishing along coastal of Jakarta city. The city would be closed from the sea by more than six-meter-high of the giant wall located few kilometers from the sea shore. This giant wall will be equipped by pumping station and inner lake as retention area. JCDS was transformed into NCICD (National Capital Integrated Coastal Development). Formed by The Central Government this NCICD will be executing the Giant Sea Wall Project. A shape of "Great Garuda" on the giant livable dyke will be created along coastal area of Jakarta (Figure 8). Around 600 trillion rupiah will be spent through scheme Public Private Partnership (PPP). Infrastructures such as highway, railway including airport will be develop on the dyke. Central of business and housing will be part of this livable dyke as well. Recently the plan is still under tight discussion.

Responding the problem of tidal inundation on the north east area of Semarang and Demak in 2016 where national road access connecting Semarang Demak and to the eastern PANTURA has been closed few times and made such a traffic jam, another dyke program in the bigger scale has been initiated. Soon, there will be TANGGUL LAUT DAN TRASE JALAN TOL in between Semarang and Demak (Figure 9). It means that the central government will built the high way which is act also as the "Giant Sea Wall" to protect the area from tidal inundation, sea level rise and perhaps the subsidence.

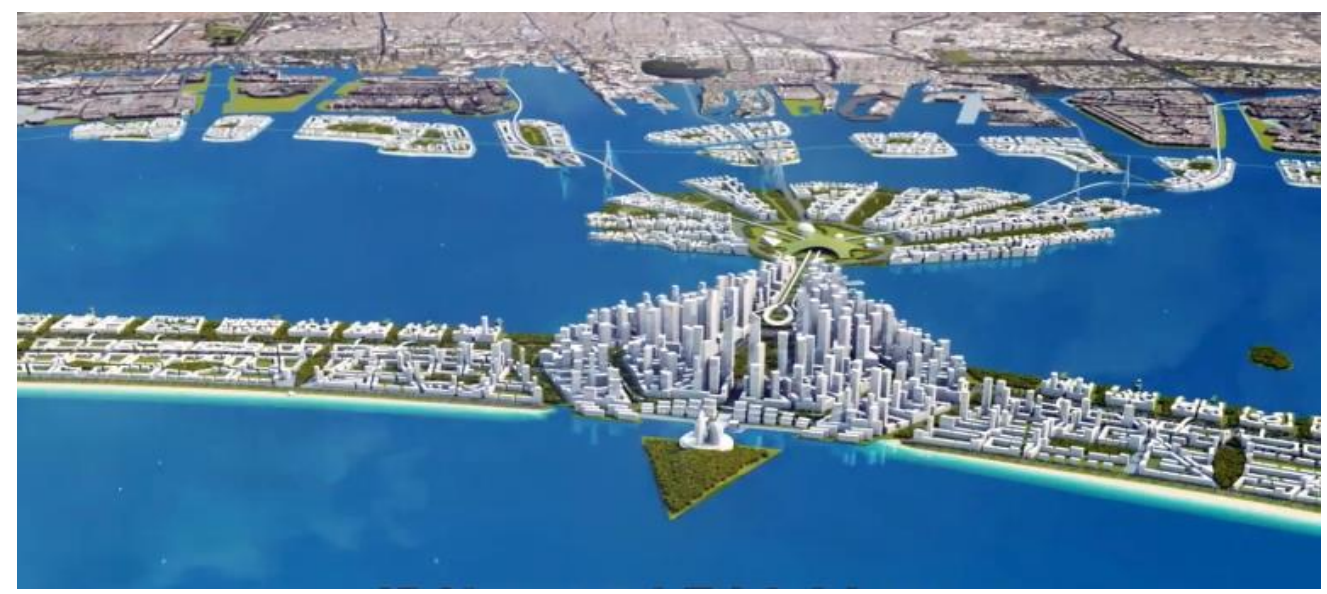

Figure 8. The scenario of "Giant Sea Wall" is establishing along coastal of Jakarta city as respond to the tidal inundation, sea level rise, and land subsidence (image courtesy of JCDS) 


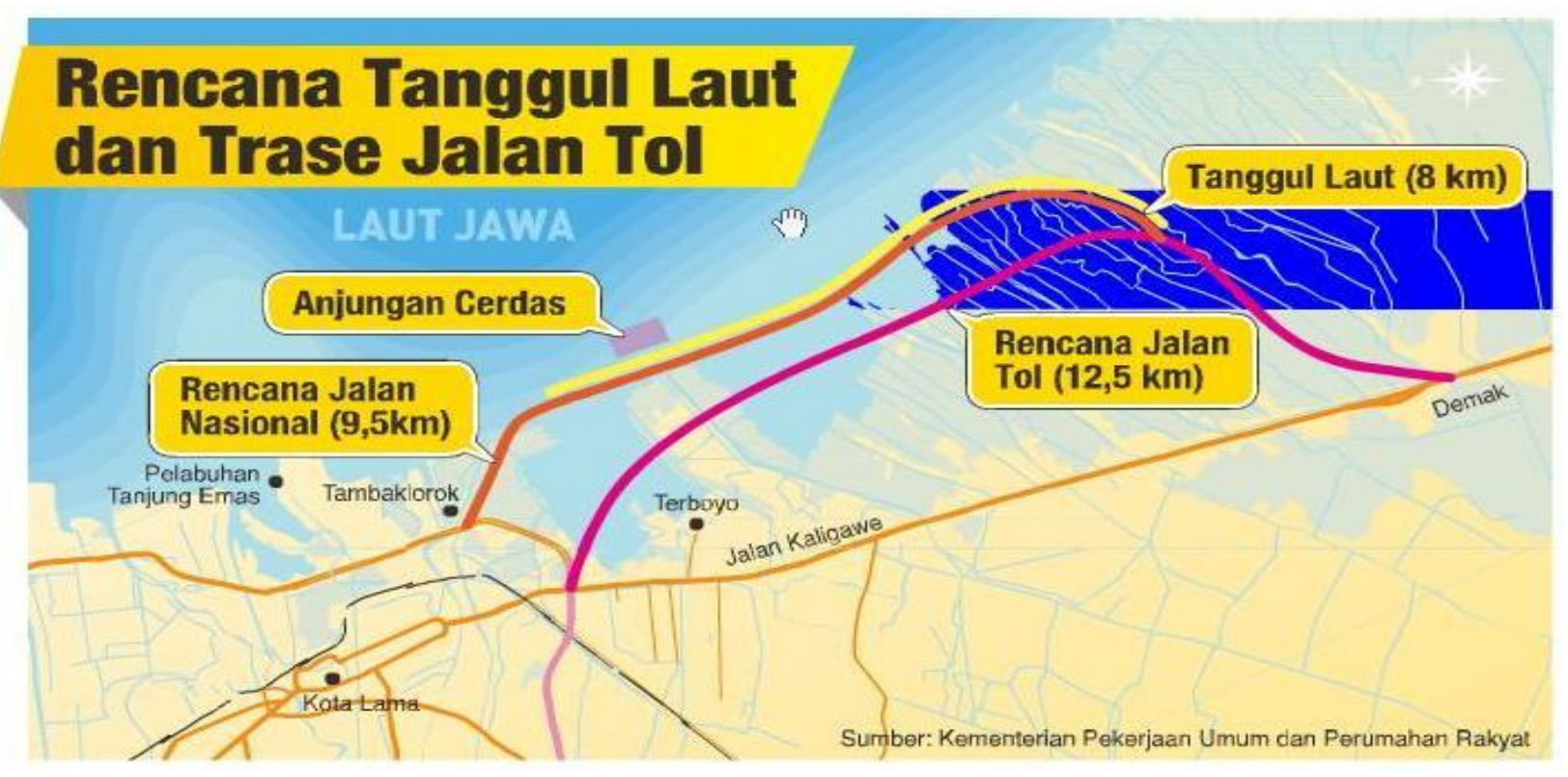

Figure 9. The scenario TANGGUL LAUT DAN TRASE JALAN TOL in between Semarang and Demak as respond to the tidal inundation, sea level rise, and land subsidence

\section{RESULTS AND DISCUSSION}

Excessive of Groundwater abstraction in combination with natural compaction of sediments and probably tectonic deformation, land setting/reclamation, loading from construction of new buildings, oil and gas extraction, underground mining, drainage of peat lands, etc. are believed to derive land subsidence. Meanwhile the increasing temperature of the earth has been brought ice to melt in the north and south Antarctica and made volume of water larger and further on made the sea level rising. Both subsidence and the sea level rise when is occurring around coastal area, after some time can derive tidal inundation. This tidal inundation may come not only at a high tide but even at the regular tide in some area. For some reason in fact the inundation comes permanently.

From all high resolution satellite image data that we have been collected, processed, and analized for PANTURA, we can see the tidal inundation and also sedimentation, abrasion are taking place in Tanggerang, Jakarta, Bekasi, Pondok Bali, Blanakan, Indramayu, Cirebon, Brebes, Tegal, Pemalang, Pekalongan, Batang, Kendal, Semarang, Demak, Gresik, Surabaya, and Sidoarjo. This tidal inundation indeed has become a disaster for some places in PANTURA. One adaptation and mitigation are to build the dyke. In Jakarta we can find dyke to the heights of about 1 up to 2 meters. Meanwhile, In Pondok Bali Blanakan we can find almost 1.5-meter dyke established to protect some village in the area. Few temporary dykes can be found along coastal area of Pekalongan. In Semarang and Demak area we can find 1- or 1.5-meter dyke along the coast. Many small dykes may be also found in others place around PANTURA from Tanggerang, Cirebon, Tegal, and up to Surabaya area. Occasionally the dyke can be seen created using the sand bag.

Dykes are supposed to be protecting the land permanently or in a very long period of time from tidal inundation, sea level rise, and perhaps the subsidence, but at the same time they are sinking quite fast in some location and failed to protect. Figure 10 shows picture of 1 meter of dyke which was failed to protect Pluit north of Jakarta from tidal inundation in 2007, and after raised 1 meter more in 2008, it is slowly sinking and about to failed again to protect the area after 2013. For the recent years, indeed, it has been elevated again for more than 1 meter. Figure 11 shows illustration where dyke has been increased two times from the first development, each for one-meter height, around Luar Batang north of Jakarta. Before being increased the dyke failed to halt the tidal inundation comes to the area. 

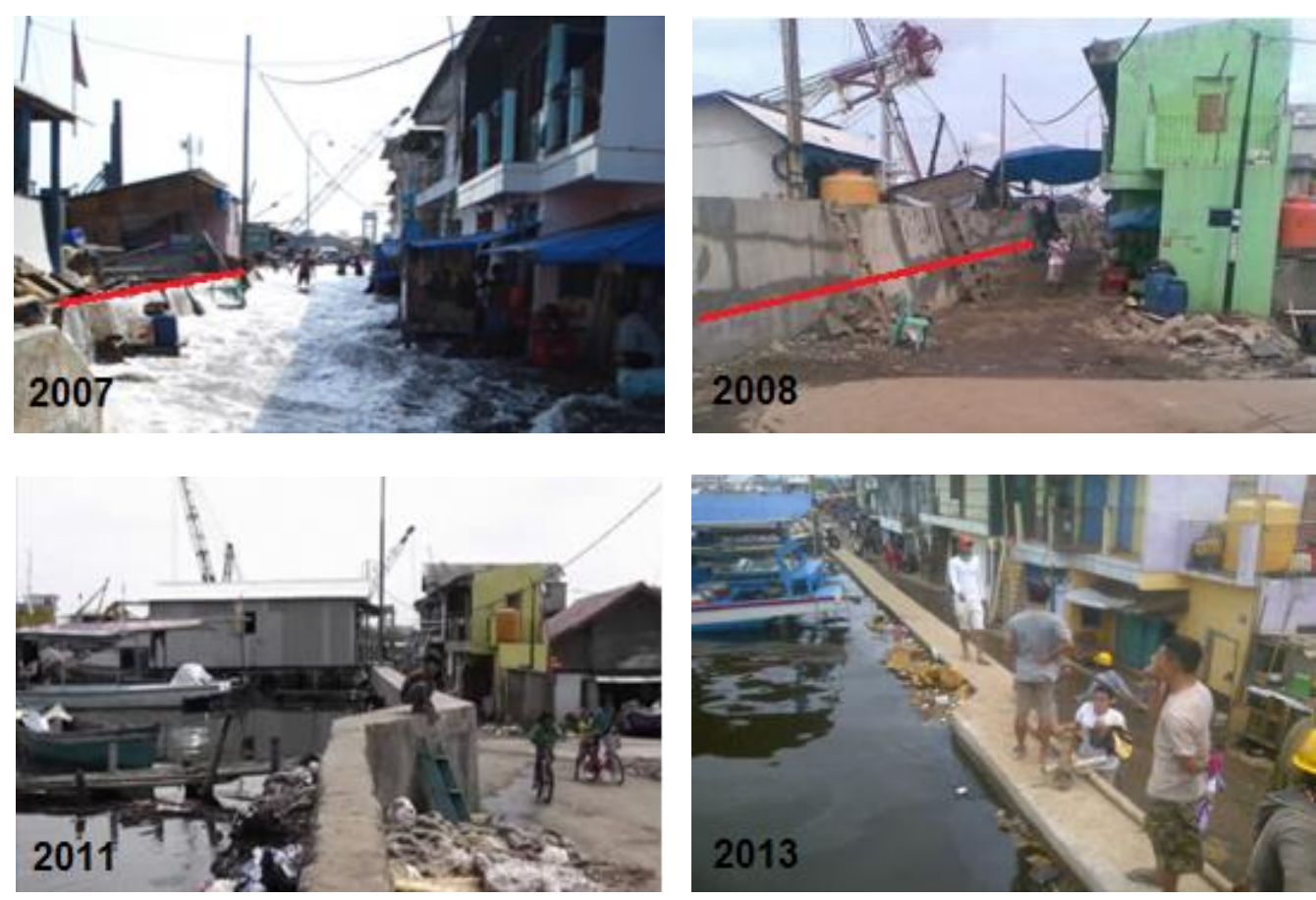

Figure 10. Illustration of dyke "sinking" in Pluit area north of Jakarta. In 2007, around 1 meter of dyke failed to protect the land, while 2008 another 1-meter elevated dyke would soon after 2013 would probably fail again
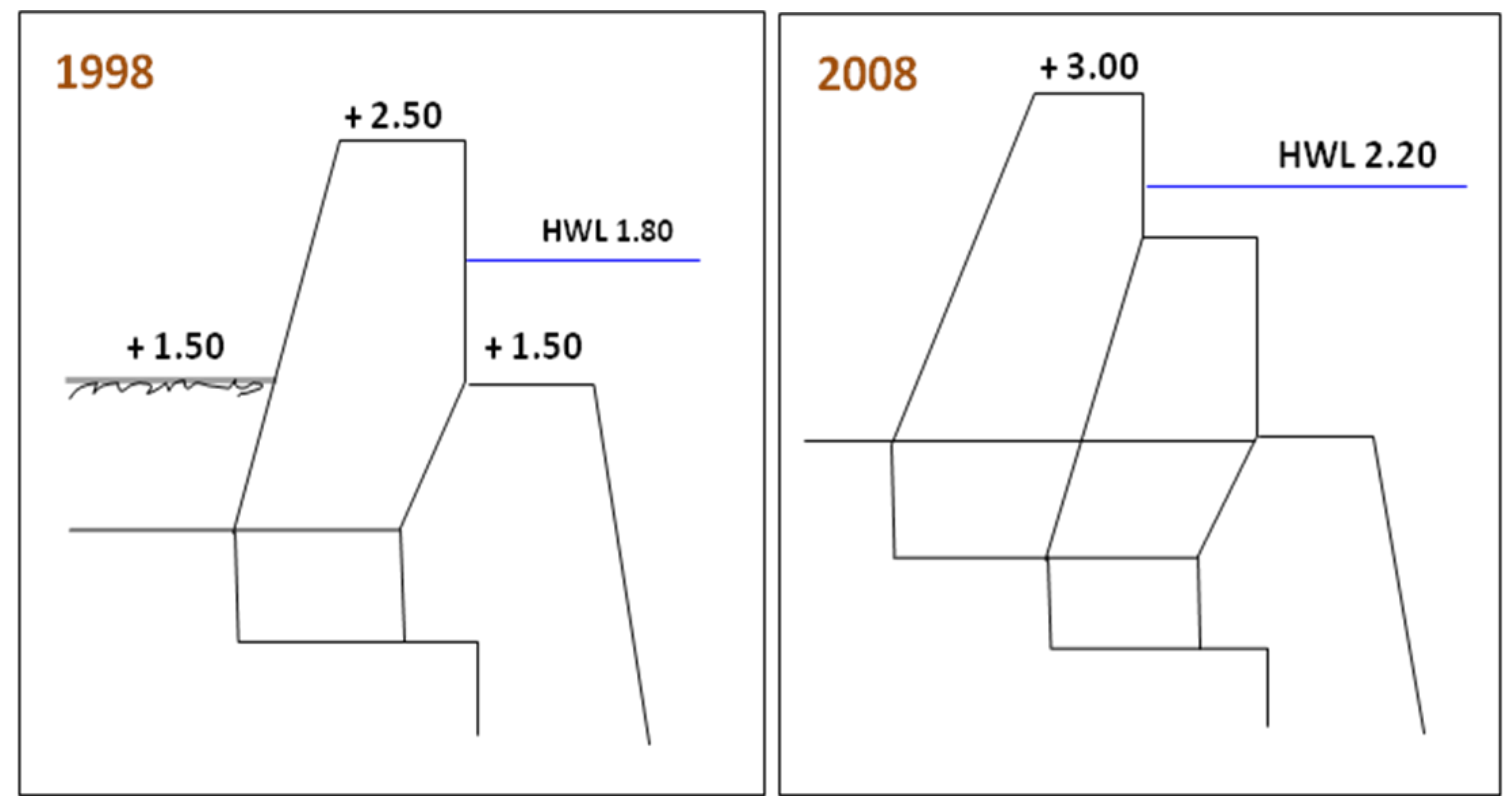

Figure 11. Illustration where dyke has been increased two times from the first development, each for onemeter height, around Luar Batang North of Jakarta

Figure 12 shows dykes that failed to protect the land from tidal inundation around north and the north east of Semarang area. As explain earlier problem of tidal inundation on the north east area of Semarang and Demak area quite severe. Almost a half of northern Semarang was experiencing tidal inundation in 2008 and 2009. In 2016 the tidal inundation has made national road access connecting Semarang Demak and to the eastern PANTURA has been closed few times and created such a traffic jam. Everybody agree that they were a disaster. Some adaptation and mitigation are necessary for avoid more disaster. Many dykes are created around Semarang, but fact in Figure 12 shows the dyke is sinking and at the certain moment failed to protect the land from tidal inundation. 
As mentioned above, responding the problem of tidal inundation on the north east area of Semarang and Demak in 2016 where national road access connecting Semarang Demak and to the eastern PANTURA has been closed few times and made such a traffic jam, another dyke program in the bigger scale has been initiated. Soon, there will be TANGGUL LAUT DAN TRASE JALAN TOL in between Semarang and Demak. It means that the central government will built the high way which is act also as the "Giant Sea Wall" to protect the area from tidal inundation, sea level rise and perhaps the subsidence. We have a question whether that is a final solution or not? It is very well explained that as long as the land subsidence is continuing; therefore, the dyke is also sinking. If we built 1-meter dyke and we have 10 centimeter per year the rate of subsidence it will make the dyke can protect the land for only 10 years.
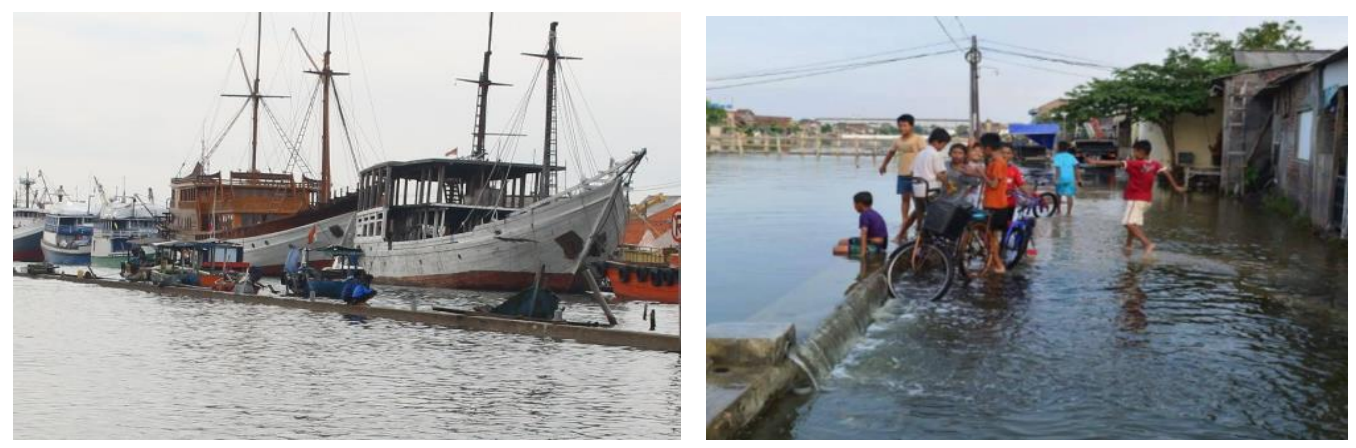

Figure 12. Illustration how is dykes has failed to protect the land from the tidal inundation around northern and the northern east of Semarang area

Figure 13 shows mangrove and dyke that supposed to protect the land from tidal inundation in Pondok Bali Blanakan area, nevertheless through times the area has suffering again tidal inundation. It is interesting to note that some people are still mixing up the tidal inundation phenomenon with the abrasion, and the land subsidence; they though mangrove can protect the land from the 'phenomenon' but turnout it cannot. Unfortunately, many places along PANTURA have programs of buildup mangrove area against tidal inundation induced by the land subsidence and the sea level rise. This approaches absolutely need to reevaluated.
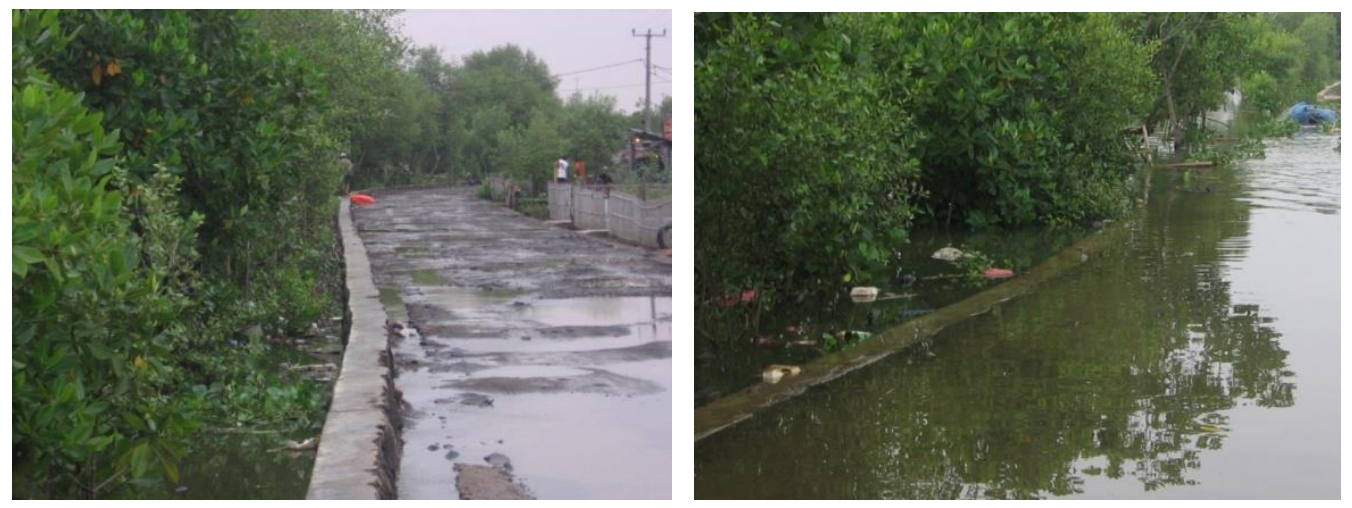

Figure 13. Mangrove and dyke that supposed to protect the land from tidal inundation in Pondok Bali Blanakan area, nevertheless through times the area has suffering again tidal inundation

Surprisingly the land subsidence in PANTURA is continuing with the linier trend (Figure 14). The rates vary mostly between $1-15$ centimeters per year. The yearly value of Jakarta's subsidence generally ranging from 1 to10 centimeter per-year and may reach 20-26 centimeter in certain place, especially in northern part of Jakarta for the recent years. The land subsidence in Pondok Bali Blanakan and Pekalongan are quite significant with rate per year for about 1-10 centimeters. The value of Semarang's subsidence is generally ranging from 1 to 17 centimeter per-year. In 5 or 10 year from now we believed the subsidence will remain if no serious action done in dealing with the land subsidence. So, we have to pay attention to the longevity of dykes from the subsidence. 

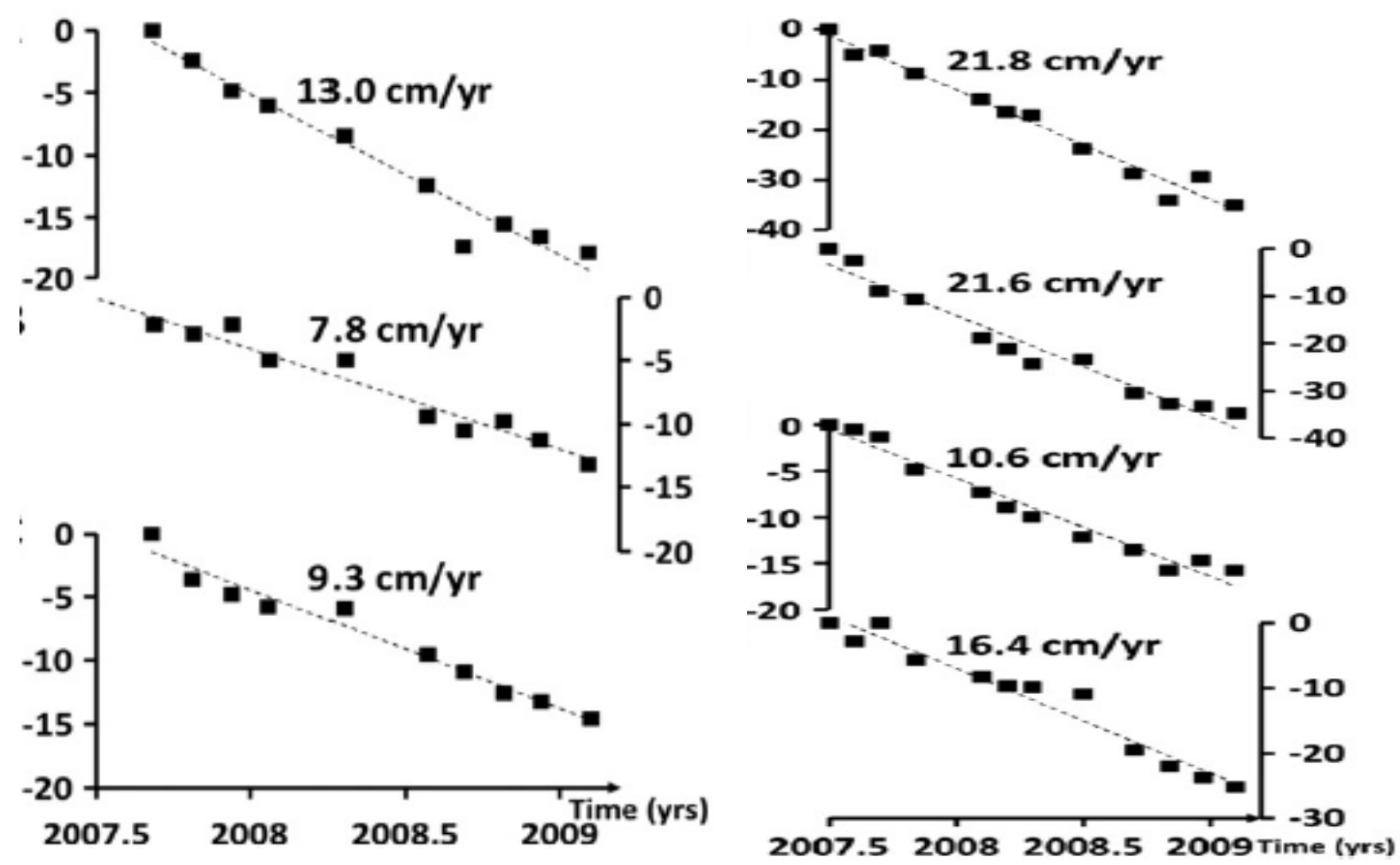

Figure 14. The linear trend of land subsidence around monitoring point in PANTURA

In the Table 2 we try to summarize the rate of sinking on dyke in some places around PANTURA (e.g. Pantai Mutiara Jakarta, Muara Baru Jakarta, Ancol Jakarta, Tanjung Mas Semarang, Tambak Loro Semarang, and Kaligawe Semarang). Along with the rate we try to calculate magnitude after 10 and 20 years. In this case we can have an idea when we can increase the dyke. Nevertheless, keep increasing the dyke is not smart solution after certain times. It can add a risk of dyke failure. Figure 15 shows illustration on how the risk is increasing when we increase the dyke. The higher the dyke the more potential to collapse since the stress is increasing from the sea volume pressure. In other hand the higher dykes will higher the risk of flooding in inner area since the water cannot easily pumped to the sea. We need very high capacity which is not easy to build and it will be so expensive.

Table 2. Rate and magnitude of dyke sinking in some places around PANTURA

\begin{tabular}{|c|c|c|c|c|}
\hline No & Area & $\begin{array}{l}\text { Rate Sinking } \\
\text { (meter/years) }\end{array}$ & $\begin{array}{l}\text { Magnitude after } 10 \text { year } \\
\text { (meter) }\end{array}$ & $\begin{array}{c}\text { Magnitude after } 20 \text { year } \\
\text { (meter) }\end{array}$ \\
\hline 1. & Pantai Mutiara Jakarta & 0.10 & 1.00 & 2.00 \\
\hline 2. & Muara Baru Jakarta & 0.12 & 1.20 & 2.40 \\
\hline 3. & Ancol Jakarta & 0.05 & 0.50 & 1.00 \\
\hline 4. & Tanjung Mas Semarang & 0.08 & 0.80 & 1.60 \\
\hline 5. & Tambak Loro Semarang & 0.10 & 1.00 & 2.00 \\
\hline 6. & Kaligawe Semarang & 0.10 & 1.00 & 2.00 \\
\hline
\end{tabular}




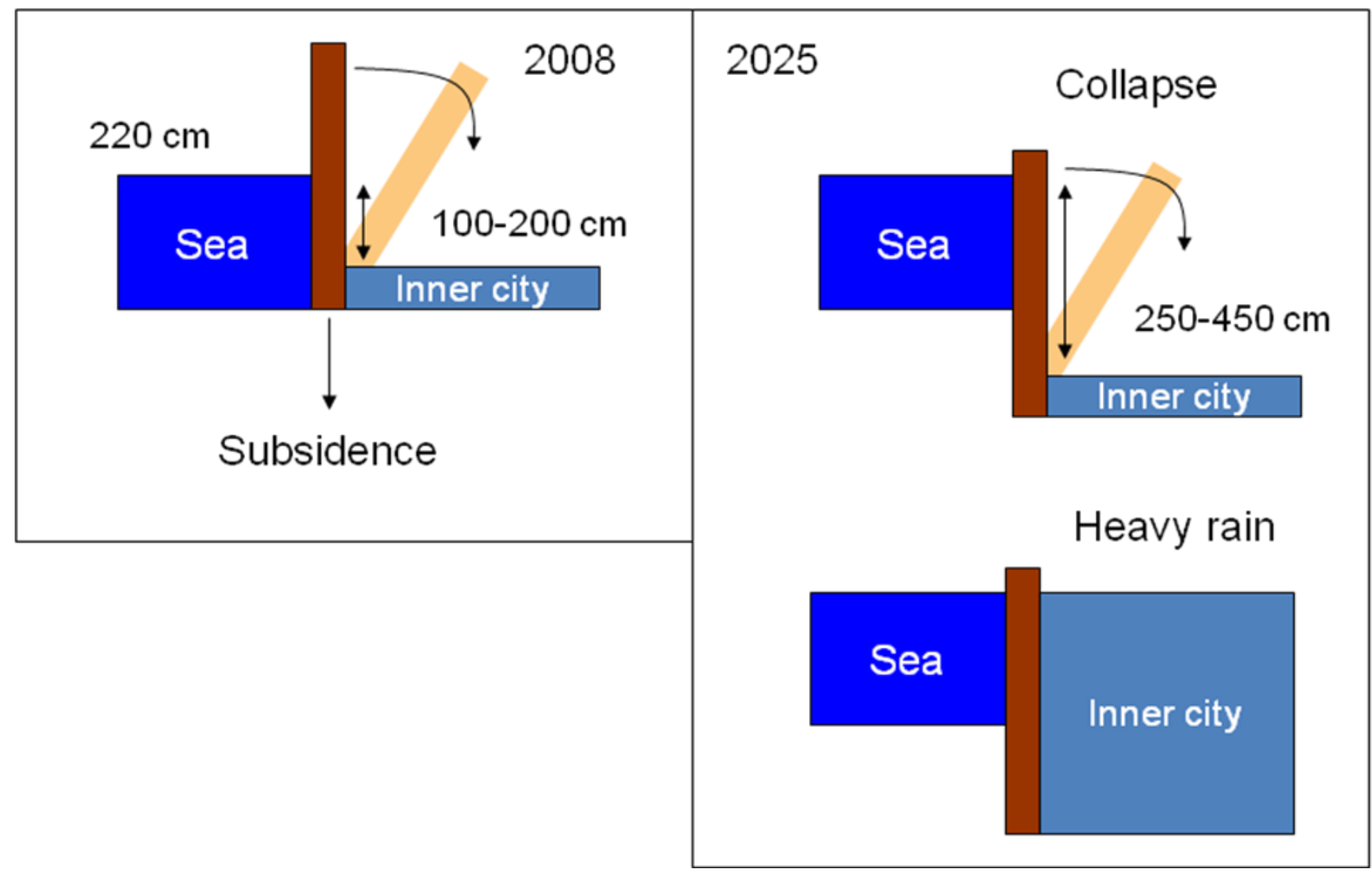

Figure 15. Illustration on how the risk is increasing when we increase the dyke

\section{CONCLUSION}

Dykes have been built against tidal inundation around PANTURA (e.g. in Jakarta, Blanakan, Pekalongan, Semarang, and Demak). Nevertheless, since the land subsidence and the sea level rise are believed to be continuing through times, the dyke is also subsiding through times. Therefore, dyke program concluded not to be a final solution. If we take a closer look, we would realize that the protection is not answering directly to the sources of subsidence and the sea level rise. If the subsidence and the sea level rise is continuing with the same rate or even accelerating, as the consequences the dyke is also subsiding and sinking. Examples above shows prove dyke is subsiding and sinking (e.g. in Jakarta and Semarang). In year 2007 the sea water overtopping the old dyke that was develops in the early 2000. In order to avoid another overtopping, one-meter height of new dyke develops above the old dyke. What happen few years later seem the sea is "rising" and about to overtopping again sometimes in the near future. That is proves the dyke is subsiding and sinking. If we even built the Giant Sea Wall "Great Garuda" or "Great High Way Sea Wall" they won't guaranty that the sea wall is not subsiding and sinking if the area is continuing to suffer land subsidence and the sea level rise.

So, along with counter measure or protection of sea wall project or dyke program, etc. we need to understand also how to stop or at least reduce the subsidence, and forget about the mangrove and the sea level rise for this purpose. First thing to do is how to carefully found the causes of the subsidence. As being explained earlier, the Land subsidence can be caused by several factors, divided into tectonic, geotechnique, and geo-hydrology factor. Tectonic given the value to subsidence in a way of plate interaction and fault activities; Geo-technique play role to subsidence from load of buildings and constructions, natural consolidation of alluvium soil, soil setting/reclamation, etc.; Meanwhile the geo-hydrology given consequences to subsidence from excessive groundwater extraction. Geo-technique and geo-hydrology strongly correlate each other through effective stresses and compaction processes, and both influenced much by soil properties. Excluding the tectonic and natural consolidation factors, all others define as anthropogenic causes. 


\section{ACKNOWLEDGMENTS}

Many thanks and appreciation give to the students who helped the investigation in the field and especially to the local people for kindly sharing the information and experience relating tidal inundation since indeed most of them are victims now from this disaster.

\section{REFERENCES}

Abidin, H., Andreas, H., Gamal, M., Gumilar, I., Napitupulu, M., Fukuda, Y., Riawan, E. (2010). Land subsidence characteristics of the Jakarta basin (Indonesia) and its relation with groundwater extraction and sea level rise. In IAH - Selected Papers on Hydrogeology (pp. 113-130). [Crossref]

Abidin, H Z. (2005). Suitability of levelling, GPS and INSAR for monitoring land subsidence in urban areas of Indonesia. GIM Int, 19(7), 12-15.

Abidin, H Z, Djaja, R., Andreas, H., Gamal, M., Hirose, K., \& Maruyama, Y. (2004). Capabilities and constraints of geodetic techniques for monitoring land subsidence in the urban areas of Indonesia. Geomatics Research Australia, 81, 45-58.

Abidin, Hasanuddin Z, Andreas, H., Djaja, R., Darmawan, D., \& Gamal, M. (2008). Land subsidence characteristics of Jakarta between 1997 and 2005, as estimated using GPS surveys. Gps Solutions, 12(1), 23-32. [Crossref]

Abidin, Hasanuddin Z, Andreas, H., Gumilar, I., Fukuda, Y., Pohan, Y. E., \& Deguchi, T. (2011). Land subsidence of Jakarta (Indonesia) and its relation with urban development. Natural Hazards, 59(3), 1753-1771. [Crossref]

Abidin, Hasanuddin Z, Djaja, R., Darmawan, D., Hadi, S., Akbar, A., Rajiyowiryono, H., ... others. (2001). Land subsidence of Jakarta (Indonesia) and its geodetic monitoring system. Natural Hazards, 23(2-3), 365387.

Chaussard, E., Amelung, F., Abidin, H., \& Hong, S.-H. (2013). Sinking cities in Indonesia: ALOS PALSAR detects rapid subsidence due to groundwater and gas extraction. Remote Sensing of Environment, 128, 150-161. [Crossref]

Hofmann-Wellenhof, B., Lichtenegger, H., \& Wasle, E. (2008). GNSS--global navigation satellite systems: GPS, GLONASS, Galileo, and more. Springer Science \& Business Media.

Koudogbo, F. N., Duro, J., Arnaud, A., Bally, P., Abidin, H. Z., \& Andreas, H. (2012). Combined X- and L-band PSI analyses for assessment of land subsidence in Jakarta. In C. M. U. Neale \& A. Maltese (Eds.), Remote Sensing for Agriculture, Ecosystems, and Hydrology XIV. [Crossref]

Kuehn, F., Albiol, D., Cooksley, G., Duro, J., Granda, J., Haas, S., ... Murdohardono, D. (2009). Detection of land subsidence in Semarang, Indonesia, using stable points network (\{SPN\}) technique. Environmental Earth Sciences, 60(5), 909-921. [Crossref]

Lubis, A. M., Sato, T., Tomiyama, N., Isezaki, N., \& Yamanokuchi, T. (2011). Ground subsidence in SemarangIndonesia investigated by ALOS PALSAR satellite SAR interferometry. Journal of Asian Earth Sciences, 40(5), 1079-1088. [Crossref]

Marfai, M. A., \& King, L. (2007). Monitoring land subsidence in Semarang, Indonesia. Environmental Geology, 53(3), 651-659. [Crossref]

Murdohardono, D, \& Sudarsono, U. (1998). Land subsidence monitoring system in Jakarta. Proceedings of Symposium on Japan-Indonesia IDNDR Project: Volcanology, Tectonics, Flood and Sediment Hazards, 243-256.

Murdohardono, D, Sudradjat, G. M., Wirakusumah, A. D., Kühn, F., \& Mulyasari, F. (2009). Land subsidence analysis through remote sensing and implementation on municipality level; case study: semarang municipality, Central Java Province, Indonesia. BGRGAI-CCOP Workshop on Management of Georisks "The Role of Geological Agencies in Government Practice of Risk Reduction from Natural Disaster, 2325.

Murdohardono, Dodid, \& Tirtomihardjo, H. (1993). Penurunan tananh di Jakarta dan rencana pemantauannya. Proceedings of the 22nd Annual Convention of the Indonesian Association of Geologists, Bandung, 6-9.

Ng, A. H.-M., Ge, L., Li, X., Abidin, H. Z., Andreas, H., \& Zhang, K. (2012). Mapping land subsidence in Jakarta, 
Indonesia using persistent scatterer interferometry (PSI) technique with ALOS PALSAR. International Journal of Applied Earth Observation and Geoinformation, 18, 232-242. [Crossref]

Nurmaulia, S. L., Fenoglio-Marc, L., \& Becker, M. (2010). Long term sea level change from satellite altimetry and tide gauges in the indonesian region, paper presented at the EGU General Assembly 2010, 2--7 May. Vienna, Austria.

Rajiyowiryono, H. (1999). Groundwater and land subsidence monitoring along the north coastal plain of Java island. CCOP Newsletter, 24(3), 19.

Sutanta, H., Rachman, A., \& Sumaryo, D. (n.d.). Predicting land use affected by land subsidence in semarang based on topographic map of scale 1: 5.000 and leveling data. Proceedings of the Map Asia 2005 Conference, 22-25. 